\title{
PERSPEKTIF GURU SEBAGAI IMPLEMENTASI PEMBELAJARAN INKUIRI TERBUKA DAN INKUIRI TERBIMBING TERHADAP SIKAP ILMIAH DALAM PEMBELAJARANSAINS
}

\author{
Pramita Sylvia Dewi ${ }^{1}$ \\ ${ }^{1}$ IAIN Raden Intan Lampung, Jl. Letnan Kolonel H. Endro Suratmin, Bandar Lampung, 35131; \\ e-mail: pramitasylvia@yahoo.co.id
}

Diterima: 15 Agustus 2016. Disetujui: 17 November 2016. Dipublikasikan: Desember 2016

\begin{abstract}
The research objective explained the process of the invention taught himself emphasized in an inquiry, recommended for students with the issues that will be analyzed further, the real action is done through a plan experiments, organizing tangible evidence until the decision with logical thinking, systematic, and critical. The entire process of inquiry that is applied in schools. According to the observer perspective in science, who adopted the role to be students understand that berprofesional in the development of scientific activities. It was based on the belief of scientific attitude as science scientist analyzing a problem with an air of confidence to dare argue, and respect the conclusions obtained using inkuri models. Researchers emphasize issues open inquiry learning usage perspective and guided inquiry that teachers against students in a class, starting with step presentation of the material until the difference between the two. The viewpoint of this research method presented by descriptive qualitative data, this method describe, explain and interpret what the object is. The data collection according to some theories of experts on the implementation of inquiry model and reality on the ground about how teachers apply it with a good inquiry. Based on the findings, it is known relationships inquiry learning implementation positively responded to the understanding of the ability of students, especially in science learning.
\end{abstract}

\begin{abstract}
Abstrak
Tujuan penelitian menerangkan proses penemuan belajar sendiri yang ditekankan dalam inkuiri, di anjurkan untuk siswa mengenal masalah yang akan di analisa lebih lanjut, tindakan nyata dilakukan melalui rencana eksperimen, melakukan pengorganisasian bukti nyata sampai kepada pengambilan keputusan denganpemikiran yang logis, sistematis, dan kritis. Keseluruhan proses inkuiri yang diterapkan di sekolah. Menurut sudut pandang peneliti dalam ilmu sains, yang mengadopsi peranan yang harus siswa pahami yakni berprofesional dalam pengembangan kegiatan ilmiah. Hal tersebut dilandasi pada keyakinan sikap ilmiah seperti ilmuan sains menganalisa suatu permasalahan dengan sikap percaya diri dengan berani berpendapat, dan saling menghargai ataskesimpulan yang diperoleh menggunakan model inkuri. Peneliti menitikberatkan permasalahan perspektif penggunaan pembelajaran inkuiri terbuka dan inkuiri terbimbing yang dilakukan guru terhadap siswa di suatu kelas, mulai dengan langkah penyajian materi sampai kepada perbedaan antar keduanya. Sudut pandang metode penelitian ini deskriptif yang tersaji secara data kualitatif, metode ini menggambarkan, menjelaskan serta menginterpretasikan objek apa adanya. Pengumpulan datamenurut beberapa teori ahli mengenai implementasi model inkuiri dan kenyataan di lapangan tentang bagaimana gurumengaplikasikan inkuiri tersebut dengan baik. Berdasarkan penemuan, diketahui hubungan implementasi pembelajaran inkuiri ditanggapi positif terhadap pemahaman kemampuan siswa khususnya dalam pembelajaran sains.
\end{abstract}

Kata kunci: inkuiri terbuka, inkuiri terbimbng, sikap ilmiah, pembelajaran sains

\section{PENDAHULUAN}

Kegiatan belajar merupakan kegiatan yang paling pokok dalam keseluruhan proses pendidikan. Salah satu masalah yang dihadapi adalah masih lemahnya proses pembelajaran. Proses pembelajaran didalam kelas masih diarahkan kepada kemampuan siswa untuk menghafal informasi, dimana (c) 2016 URPI, FTK IAIN Raden Intan Lampung informasi tersebut dihubungkan dengan kehidupan sehari-hari yang secara aktif mengembangkan potensi dirinya untuk memiliki kekuatan spiritual keagamaan, pengendalian diri, kepribadian, kecerdasan, akhlak mulia, serta keterampilan yang diperlukan dirinya, masyarakat, bangsa dan Negara. 
Faktanya pada pembelajaran sains khususnya, selama ini proses belajar dan mengajar hanya sekedar menghafal fakta, prinsip dan teori saja (Trianto, 2014). Pembelajaran sains tidak cukup dengan penjelasan dan mendengarkan saja, melainkan siswa akan lebih mudah memahami materi dan konsep-konsep jika dilakukan dengan kegiatan menemukan konsep itu sendiri. Hal ini sesuai dengan pendapat Trianto, bahwa proses belajar mengajar sains lebih ditekankan pada pendekatan keterampilan proses, hingga siswa dapat menemukan fakta, membangun konsep, teori dan sikap ilmiah sendiri yang pada akhirnya dapat berpengaruh positif terhadap kualitas produk pendidikan.

Kenyataannya siswa masih lemah dalam sains, padahal perkembangan zaman sains sangat diperlukan untuk berkomunikasi dan pengembangan teknologi. Terbukti dari hasil penelitian tentang asesmen hasil belajar sains pada level Internasional yang diselenggarakan oleh Organization for Economic Cooperation and Development (OECD) tenatangProgramme for International Student Assessmen(PISA), skor literasi sains yang diperoleh siswa tergolong pada level yang masih rendah. Kecakapan siswa pada level ini memiliki pengetahuan sains yang terbatas dan hanya bisa diterapkan pada beberapa situasi saja secara eksplisit (Suryosubroto, 2009). Menurut Hasil dari penelitian lainmenunjukkan masih rendahnya peningkatan kemampuan sains pada siswa SMP (Artati, 2013). Selanjutnya, Firman juga mengungkapkan rendahnya pembelajaran sains siswa Indonesia berkaitan erat dengan adanya kesenjangan antara pembelajaran IPA yang diterapkan di sekolah dan tuntutan PISA (Firman, 2007). Sejalan dengan perkembangan kurikulum di Indonesia yang lebih menekankan pada pendekatan saintifik, dimana siswa dijadikan sebagai pusat utama dalam proses pembelajaran (Dewi, 2015). Tujuan pembelajaran dengan pendekatan saintifik didasarkan pada keunggulan pendekatan tersebut, antara lain: (1) meningkatkan kemampuan kemampuan berpikir tingkat tinggi, (2) membentuk kemampuan siswa dalam menyelesaikan masalah secara sistematik, (3) terciptanya pembelajaran dimana siswa merasa bahwa belajar itu merupakan suatu kebutuhan.
Berhubungan dengan hal ini, (DralingHammond \& Brannsford, 2005) menyatakan bahwa guru hendaknya mampu menemuan cara untuk mendorong dan mengembangkan potensi siswa. Tanpa usaha ini sulit untuk tercipta siswa yang memliki kemampuan pemahaman yang baik.

Model pembelajaran inkuiri merupakan salah satu inovasi pembelajaran yang dapat mengarahkan siswa untuk melakukan penemuan sehingga siswa dapat memperoreh pengetahuan yang lebih mendalam. Model pembelajaran tersebut menekankan bagaimana seseorang berpikir dan bagaimana dampaknya terhadap cara pengolahan informasi. Inkuiri yang diterapkan dalam proses pembelajaran dapat meningkatkan kemampuan siswa dalam melakukan observasi dan mengemukakan jawaban atas suatu permasalahan melalui interpretasi data hingga diperoleh suatu kesimpulan.

Berdasarkan tingkat kompleksitasnya pembelajaran inkuiri dibedakan menjadi tiga tingkatan (Trowbridge, 1990) . Pertama adalah pembelajaran penemuan (discovery inquiry). Kedua adalah pembelajaran inkuiri terbimbing (guided inquiry). Tingkatan paling kompleks adalah pembelajaran inkuiri terbuka (open inquiry). Persamaan ketiga tingkatan inkuiri tersebut adalah ketiganya melibatkan keterampilan proses sains dan kemampuan dasar bekerja ilmiah. Pada penelitian ini pembelajaran inkuiri yang diterapkan yaitu Open Inquiry dan Guided Inquiry. Model pembelajaran ini dipilih karena pada setiap langkah pembelajaran pada kedua model pembelajaran ini memberikan kesempatan kepada siswa untuk melakukan pengamatan, bertanya, mengajukan hipotesis, mengumpulkan data, melakukan percobaan dan membuat kesimpulan. Diharapkan dapat membuat siswa belajar lebih mengerti, serta siswa mampu menjelaskan pengetahuan berdasarkan bukti dari proses percobaan yang mereka lakukan.

Ilmu sainsterutama dalam kehidupan perlu usaha dari berbagai pihak untuk mengaplikasikan sehingga bermanfaat. Telah banyak masyarakat dan pemerintah khususnya dalam bidang pembelajaran melakukan peningkatkan mutu belajar di sekolah-sekolah, salah satunya terlepas dari peranan guru dan siswa yakni, 
pengembangan kurikulum nasional pendidikan dan peningkatan mutu manajemen sekolah.

Pembelajaran tersebut dilakukan mereka dengan mampu mengambil keputusan yang tepat saat menggunakan konsep-konsep ilmiah. Selama ini kurangnya faktor kreatifitas pada pembelajaran berlangsung, sehingga sering ditemukan pembelajaran yang hanya berpusat pada guru. Sesuai kondisi di atas, salah satu alternatif membangkitkan motivasi siswa dalam pembelajaran sains adalah menggali kegiatan ilmiah. Alternatif yang tepat yaitu dengan penerapan model inkuiri dalam pembelajaran, khususnya dalam sains.

Inkuiri berarti pertanyaan, pemeriksaanatau penyelidikan, dimana pada tahapannya mengandung proses-proses tingkatan berbeda.Inkuiri berarti proses bertanya atau mencari jawaban pada intinya. Trowbridge \& Bybee (Suparno, 2007) menyatakan bahwa inquiry adalah proses para saintis mengajukan pertanyaan tentang alam tentang dunia ini dan bagaimana mereka secara sistematis mencari jawabannya. Pembelajaran inkuiri berarti bertanya untuk mencari sebuah tahu permasalahan dengan menggunakan prinsip atau metode ilmiah (Gulo, 2002). Pembelajaran tersebut melibatkan emosional, sehingga kegiatan prosedur ilmiah dapat terarah dan menjawab keingintahuan.

Hosnan menyatakan ciri-ciri dari pembelajaran inquiry adalah sebagai berikut: (1) menempatan belajar yang baik, dimana seorang guru dan siswa memiliki kapasitasnya masing-masing (2) percaya diri (self belief), merupakan sikap yang dimiliki siswa saat merespon penapat ataupun pemikiran yang akan di utarakan(3) memiliki tujuan yang jelas, dalam hal ini kesepakatan merupakan kunci bersama saat menganalisa suatu permasalahan (Hosnan, 2014). Selain itu Hosnan menyatakan adanya prinsip-prinsip: (1) intelektual, (2) komunikasi, (3) bertanya, (4) keterbukan. Kemampuan siswa untuk menjawab setiap pertanyaan pada dasarnya sudah merupakan sebagian dari proses berpikir yang secara alami telah terarah sesuai dengan kegiatan ilmiah yang mereka lakukan dalam proses mengikuti suatu pembelajaran yang bersifat inkuiri (Hosnan, 2014).

Hamalik menambahkan adanya kelompok-kelompok dalam inkuiri, karena suatu grup merupakan sarana yang efektif dari keberagaman pendapat dalam pemecahan masaah yang sedang di ujikan (Hamalik, 1991). Berdasarkan kegatan yang banyak digunakan saat ini adalah inkuiri terbimbingmasih diminati oleh sebagian guru dalam menerapkan pembelajaran yang dilakukan secara langsung di kelas, karena guru meyakini proses mencari tahu siswa terhadap suatu permasalahan belum optimal jika tanpa arahan yang jelas dalam kata lain petunjuk oleh guru yang bertujuan membuktikan kebenaran .

Staver dan Bay (Vajoczki, Watt, Vine, \& Liao, 2011) Inkuiri terstruktur bertujuan untuk memperkenalkan konsep, kosa kata, proses, keterampilan, dan metode investigasi. Hal tersebut membimbing siswa menuju penemuan tertentu, memberikan pengalaman dasar, dan mengembangkan keterampilan.

Inkuiri terbimbing berbeda dengan inkuiri terstruktur, guru memberikan masalah dan isu-isu awal penyelidikan. Siswa menyusun prosedur sendiri untuk melakukannya. Inkuiri terbimbing digunakan untuk pemahaman konseptual dan keterampilan siswa, mengembangkan kreativitas, dan memahami pengertian. Sementara pada inkuiri terbuka siswa diminta untuk merumuskan sendiri masalah dan mengembangkan prosedur untuk menyelidiki dan memecahkan masalah. Tujuan dari inkuiri terbuka adalah untuk merumuskan suatu pertanyaan, mengembangkan kreativitas dalam menjawab pertanyaan secara bebas, adanya bukti, dan kritis. Sejalan dengan pendapat (Rustaman, 2005) bahwa inkuiri terbmbing 
lebih menekankan dalam diskusi. Pada inkuiri terbuka, hasil pemecahan masalah mungkin mengarah pada pertanyaan baru dari masalah sebelumnya.

Suryosubroto dalam bahasan nya memprediksikan jika suatu pembelajaran terutama imu sains diterapkan di sekolah harus mampu membangkitkan gairah pada siswa untuk belajar, baik pemahaman ilmu maupun sikap seorang saintis (Suryosubroto, 2002). Wujud dari proses belajar mengajar menggunakan inkuiri dapat berupa pembinaan yang dimengerti siswa, dimana guru hanya menjadi teman belajar saja, bukan secara utuh memegang kendali kelas, perencanaan merupakan hal yang penting dipersiapkan, agar tidak lagi terjadi pengajaran secara tradisional yang monoton.

Sikap ilmiah dalam pembelajaran sangat diperlukan oleh siswa karena dapat memotivasi kegiatan belajarnya. Dalam sikap ilmiah terdapat gambaran bagaimana siswa seharusnya bersikap dalam belajar, menanggapi suatu permasalahan, melaksanakan suatu tugas, dan mengembangkan diri. Hal ini tentunya sangat mempengaruhi hasil dari kegiatan belajar siswa ke arah yang positif. Melalui penanaman sikap ilmiah dalam belajar siswa memiliki kemungkinan untuk lebih dapat belajar memahami dan menemukan. Lang \& Evan menyatakan bahwa sikap ilmiah akan muncul pada diri siswa apabila secara terus menerus dikuatkan. Misalnya pada saat guru secara teratur menggunakan metode ilmiah, meskipun dengan menggunakan alat dan bahan yang sederhana, hal tersebut akan meningkatkan sikap positif siswa terhadap sains (Lang, 2006).

Sikap ilmiah dapat dianggap sebagai sesuatu yang kompleks dimana nilai-nilai dan norma-norma yang mengikat pada ahli science. Carin \& Sund, menyatakan bahwa pendidikan sains harus melahirkan suatu sikap dan nilai-nilai ilmiah (Carin \& Sund, 1997). Nilai dan sikap ilmiah ini penting dimiliki dan diperlihatkan oleh siswa pada saat mereka belajar sains. Tingkat sikap ilmiah siswa dapat dilihat dari bagaimana mereka memiliki rasa keingintahuan yang sangat tinggi, memahami suatu konsep baru dengan kemampuannya tanpa ada kesulitan, kritis terhadap suatu permasalahan yang perlu dibuktikan kebenarannya, dan mengevaluasi kinerjanya sendiri. Hal-hal inilah yang dapat membantu siswa belajar secara ilmiah, terstruktur, dan mandiri.

Menurut Azwar, metode pengungkapan sikap ilmiah dalam bentuk self-report yang hingga kini dianggap dapat diandalkan adalah dengan menggunakan daftar peryataan-peryataan yang harus dijawab oleh individu yang disebut skala sikap, diakui penggunaan skala sikap ini lebih unggul dibandingkan dengan metode penanyaan langsung dan metode pengamatan perilaku (Azwar, 2013). Skala sikap (Attitude Scales) berupa kumpulan pernyataan-pernyataan mengenai suatu objek sikap. Dari respon subjek pada setiap pernyataan kemudian dapat disimpulkan mengenai arah dan intensitas sikap seseorang. Salah satu sifat skala sikap adalah isi pernyataan yang dapat berupa pernyataan langsung yang jelas ukuran tujuan ukurannya akan tetapi dapat pula berupa pertanyaan tidak langsung yang tampak kurang jelas tujuan ukurannya bagi responden.

Penulis melakukan pnelitian ini menggunakan metode deskriptif. Untuk lebih jelasnya data yang tersaji dipaparkan secara kualitatif, dimana metode tersebut tidak memberikan perlakuan, atau pengubahan pada variabel-variabel bebas, namun menggambarkan keadaan yang sesungguhnya (McMillan, J \& Schumacher, 2001). Sehingga metode ini menggambarkan, menjelaskan serta menginterpretasikan objek apa adanya.Instrumen yang dipilih penulis menggunakan pengumpulan data, menggunakan kajian perspektif, menurut beberapa teori ahli mengenai implementasi model inkuiritentang bagaimana seorang 
guru menggunakan penerapan aplikasi nyata di sekolah.

\section{PEMBAHASAN}

Permasalahan yang terjadi dalam sebagian besar kasus penyajian pembelajaran inkuiri di kelas, saat di ajukannya beberapa pertanyaanpertanyaandari siswa terkait suatu isu yang di paparkan guru sebelumya, yang memang daya serap mereka belum secara spesifik. Meski sulit menerapkannya diyakini adanya faktor yang menghambatsalah satunya adalah proses menghabiskan banyak waktu pemahaman. Selain itu, memiliki seorag fasilitator dituntut lebih paham dan memiliki kemampuan mengajar dengan inkuiri. Oleh karena itu, perlu dikembangkannya suatu program untuk calon guru agar lebih memahami inkuiri.

Berdasarkan hasil survey Colorado Learning Attitudes about Science Survey (CLASS) menyatakan bahwa penerapan Physics by Inquiry (PbI) pada calon guru sangat membantu dalam menyiapkan calon guru yang dapat menerapkan inkuiri dalam pembelajaran. Kemajuan menambah wawasan tentunya sangat diperlukan. PbI ini merupakan cara efektif yang diterapkan ketika pembelajar tersebut sudah benarbenar paham bagaimana cara mengajar berbasis inkuiri.

Bruce \& Weil (1980, dalam Hosnan, 2014), menyebutkan bahwa latihan inkuiri dapat menambah pengetahuan sains, menghasilkan kemampuan berpikir kreatif, keterampilan dalam memperoleh dan menganalisis data (Hosnan, 2014; Weil \& Joyce, 2000). Joyce menyatakan bahwa dampak instruksional dari latihan inkuiri adalah membentuk semangat berkreasi, kemandirian dalam belajar, menghormati perbedaan pandangan dan sadar bahwa peristiwa pada proses pembelajaran akan secara tentatif, dengan banyak perubahan yang tidak tetap.

Latihan yang diajarkan kepada siswa oleh guru hanya boleh mendapatkan jawaban ya atau tidak, bukan bersifat uraian terperinci. Untuk lebih lanjut, cara tersebut digunakan untuk meminimalisir arahan guru yang terlalu mengarah pada petunjuk baku, karena pada kesepakatan di awal sebagai seorang ilmuan siswa dituntut mampu membahas masalah secara mandiri berkenaan pada perspektif mereka mengasah suatu kajian teori yang dipermasalahkan atau dikaji secara lebih mendalam.

Temuan dilapangan terlihat bahwa ilmu sains ini lebih cocok berupa pertanyaan tentang alat, bahan dan cara kerja dalam percobaan yang secara langsung berkenaan dengan paktikum di laboratorium. Disini siswa akan dilatih sendiri masalah dan menyelesaikan sendiri dengan menggunakan eksperimen atau percobaan sesuai petunjuk yang telah diberikan. melakukan penyelididkan ilmiah dan berlatih untuk membuat kesimpulan dan membuat laporan terkait yang dilakukan (Joyce \& Calhoun, 2009).

Inti dari model inkuiri adalah melibatkan siswa dalam masalah penelitian yang benar-benar orisinil berupa suatu investigasi, yang membantu mereka dalam mencari masalah keilmuan. Didukung juga oleh pendapat Carin bahwa pembelajaran sains melalui proses aktif, dapat membentuk sikap ilmiah (Carin \& Sund, 1997). Sebagaimana disarankan oleh Bruner partisipasi memperoleh pengalaman dan melakukan eksperimen (Dahar, 2011).

Sikap ilmiah perlu dikembangkan pada siswa karena di dalam belajar sains tidak hanya sekedar aspek kognitif, aspek afektif juga merupakan bagian yang penting dalam perencanaan, penyampaian, dan evaluasi suatu pembelajaran. Carin dan Sund berpendapat pendidikan sains harus melahirkan suatu sikap dan nilai ilmiah (Carin \& Sund, 1997). Sikap ilmiah sangat mendukung kegiatan belajar siswa ke arah yang positif (Slameto, 2010). Berdasarkan hasil observasi menunjukkan sikap ilmiah siswa masih rendah, sehingga perlu dioptimalkan dan diberdayakan. Sikap 
ilmiah seperti sikap ingin tahu, mengutamakan bukti, sikap skeptis, menerima perbedaan, dapat bekerja sama, dan bersikap positif terhadap kegagalan menjadi hal penting untuk dimiliki setiap siswa (Carin \& Sund, 1997).

Penelitian tentang sikap ilmiah yang telah dilakukan oleh Iswani salah satu faktor yang perlu dipertimbangkan dalam proses pembelajaran guna meningkatkan hasil belajar siswa. Rendahnya sikap ilmiah siswa dikarenakan proses pembelajaran yang diterapkan selama ini masih menggunakan diskusi informasi (Iswani, 2008). Siswa seharusnya menjadi lebih aktif dalam mencari jawaban dari setiap pertanyaan yang diberikan, sebagaimana implementasi dari kurikulum 2013 yang mengharuskan pembelajaran berpusat pada siswa. Berdasarkan hasil observasi dan wawancara di sekolah, ternyata guru di sekolah masih sangat jarang menggunakan model pembelajaran yang sesuai dengan kurikulum.

Wartini mengemukakan penguasaan konsep dapat meningkat disebabkan siswa yang memperoleh kemampuan memahami lebih aktif dan menemukan konsepnya sendiri(Wartini, 2014). Berg et al menyatakan bahwa Open Inquiry menunjukkan hasil yang positif terhadap hasil belajar, waktu persiapan dan kegiatan saat di laboratorium. Peneliti memperkirakankelas control yang selalu dibandingkan dengan eksperimen tidaklah selalu kalah (Zion \& Sadeh, 2011). Di mana kelas eksperimen dikondisikan dengan diterapkan pembelajaran berbasisi inkuiri. Sedangkan pada kelas kontrol diterapkan pembelajaran pada umumnya, guru yang lebih bermain peran, pembuktikan ini di lihat dari hasil post-tes para siswa. Oleh karena itu kegiatan siswa tidak semestinya dibatasi hanya dengan mendengarkan materi dari guru secara sepihak.

\section{SIMPULAN}

Berdasarkan pembahasan, di dapatkan kesimpulan ini perlu dilakukan peninjauan kembali terhadap waktu pelaksanaan pembelajaran lebih optimal. Singkatnya waktu pelaksanaan pembelajaran menjadi salah satu faktor yang mempengaruhi proses belajar dengan penerapan inkuri.

Belum terbiasanya pembelajaran yang diterapkan menyebabkan adanya kebingungan siswa dalam melaksanakan langkah pembelajaran. Selain itu siswa juga belum terbiasa melakukan percobaan di dalam laboratorium, sehingga membuat siswa kebingungan dalam memulai percobaan. Ada baiknya untuk pembelajaran selanjutnya siswa dibiasakan belajar dengan menggunakan metode percobaan di laboratorium agar proses pembelajaran tidak monoton.

Saran perbaikan pada penelitian selanjutnya ada baiknya untuk siswa yang menggunakan model pembelajaran Open Inquiry tidak dilepas begitu saja dalam melakukan langkah pembelajaran, guru hendaknya lebih memberikan bimbingan kepada siswa khususnya pada saat melakukan percobaan, karena untuk kelas ini siswa terlihat masih belum terbiasa untuk melakukan percobaan tanpa bimbingan dari guru. Pada siswa yang menggunakan model pembelajaran Guided Inquiry ada baiknya untuk kegiatan percobaan dan membuat kesimpulan siswa tidak secara penuh diberikan bimbingan oleh guru agar siswa dapat menuangkan ideidenya. Pada kegiatan percobaan siswa cukup dituntun dengan LKS saja, sehingga sikap ilmiah siswa dapat berkembang secara maksimal dan pada kegiatan merumuskan kesimpulan hendaknya siswa melakukannya secara mandiri agar siswa dapat berpikir secara aktif dalam mendeskripsikan hasil temuannya.

Terkait dengan proses pembelajaran yang berlangsung pada pengisian LKS yang dikerjakan oleh kelompok siswa, disarankan sebelumnya jika melakukan penelitian sejenis ini untuk melakukan uji coba terbatas agar permasalahan yang di kaji sesuai kriteria pada tujuan pembelajaran. Profil sikap sains siswa melalui instrumen 
yang diberikan, kenyataannya memiliki hasil uji yang masih terbatas. Oleh karena itu diperlukan istrumen self efficacy yang dapat mengungkapkan sikap sains siswa secara lebih akurat.

Diperlukan media yang mendukung saat penyajian pembelajaran, misalnya ketika keterikatan konsep pada konteks sains dengan materi pembelajaran harus saling berhubungan dan lebih baik ditayangkan di awal dan di akhir pembelajaran. Guru menyiapkan semua perangkat pembelajaran sebelum memulai proses pengajaran menggunakan implementasi pendekatan saintifik, adanya feedback tersebut meminimalisir keadaan yang umumnya selalu terjadi di sekolah dengan melakukan pengarahan yang baik oleh guru, serta mampu menciptakan kreatifitas dalam melakukan kegiatan eksperimen atau demonstrasi sederhana dalam kegiatan pembelajaran sains.

\section{DAFTAR PUSTAKA}

Artati, J. (2013). Analisis kemampuan literasi sains siswa SMP dalam pembelajaran IPA terpadu pada tema Cuaca Ekstrim. Universitas Pendidikan Indonesia Bandung.

Azwar, S. (2013). Sikap Manusia, Teori dan Pengukurannya (ke 2). Yogyakarta: Pustaka Pelajar.

Carin, A., \& Sund, B. (1997). Teaching Science Through Discovery. Ohio: Merril Publishing Co.

Dahar, R. W. (2011). Teori-Teori Belajar \& McMillan, J, H., \& Schumacher, S. (2001). Research in Dducation: A Conceptual Introduction (5th ed.). New York: Longman.

Rustaman, N. (2005). Strategi Belajar Mengajar Biologi-Cet 1. Malang: Universitas Negeri Malang.

Slameto. (2010). Belajar dan Faktor-Faktor yang Mempengaruhinya. Jakarta: Rineka Cipta.

Suparno, P. (2007). Metodologi Pembelajaran Fisika Konstruktivistik
Pembelajaran. Jakarta: Erlangga.

Dewi, P. S. (2015). Implementasi Pendekatan saintifik Terhadap Proses Aktivitas Guru dan Siswa Pada Pembelajaran IPA Terpadu. In Proceeding SNIPS EDUCATION ITB.

Draling-Hammond, L., \& Brannsford, J. E. (2005). Preparing Teacher for A Changing World. San Francisco: JosyBass Publishing.

Firman, H. (2007). Analisis Literasi Sains Berdasarkan Hasil PISA Nasional Tahun 2006. Jakarta: Pusat Penelitian Pendidikan Balitbang Depdiknas.

Gulo, W. (2002). Strategi BelajarMengajar. Jakarta: Grasindo.

Hamalik, O. (1991). Strategi Belajar Mengajar. Bandung: CV Sinar Baru.

Hosnan, M. (2014). Pendekatan Saintifik dan Kontekstual dalam Pembelajaran Abad 21 Kunci Sukses Implementasi Kurikulum 2013. Bogor: Ghalia Indonesia.

Iswani, S. (2008). Pembelajaran Biologi Metode Inkuiri Terbimbing Menggunakan Lab Riil dan Lab Virtual Ditinjau dari Sikap Ilmiah dan Gaya Belajar Siswa. Universitas Sebelas Maret Solo.

Joyce, B. W. M., \& Calhoun, E. (2009). Models of Teaching. Model-Model Pembelajaran. Yogyakarta: Pustaka Pelajar.

Lang, H. R. (2006). Models, Strategies, and Methods for Effective Teaching. USA: Pearson Education Inc.

dan Menyenangkan. Yogyakarta: Universitas Sanata Dhrama.

Suryosubroto. (2002). Proses Belajar Mengajar di Sekolah. Jakarta: PT. Rineka Cipta.

Suryosubroto, B. (2009). Proses Belajar Mengajar di Sekolah. Jakarta: PT Rineka Cipta.

Trianto. (2014). Model Pembelajaran Terpadu. Jakarta: Bumi Aksara.

Trowbridge, L. W. (1990). Becoming a Secondary School Science Teacher. 
Melbourne: Merril Publishing Co.

Vajoczki, S., Watt, S., Vine, M., \& Liao, X. (2011). Inquiry Learning: Level, Discipline, Class Size, What Matters? International Journal for the Scholarship of Teaching and Learning. Wartini. (2014). Penerapan Pembelajaran Berbasis Praktikum Melalui Inkuiri Terbimbing dan Verifikasi Pada Konsep Fotosintesis Terhadap Penguasaan Konsep dan Keterampilan
Proses Sain Siswa SMP. Universitas Pendidikan Indonesia Bandung.

Weil, M., \& Joyce, B. R. (2000). Models of Teaching (6th ed.). Boston: Allyn and Bacon.

Zion, M., \& Sadeh, I. (2011). Which Type of Inquiry Project Do High School Biology Students Prefer: Open or Guided. Research Science Education, 42, 831-848. 